\title{
ANALISIS KEMAMPUAN PENGOLAHAN DATA BERBASIS MS. EXCEL PADA MAHASISWA SEMESTER AKHIR UNIVERSITAS TEUKU UMAR
}

\section{Analysis of Data Processing Ability using Ms Excel for Final-Year Students of Teuku Umar University}

\author{
Cukri Rahmi Niani ${ }^{1 *}$, Norisca Lewaherilla ${ }^{2}$ \\ ${ }^{1}$ Prodi Teknologi Informasi, Fakultas Teknik, Universitas Teuku Umar \\ ${ }^{2}$ Prodi Matematika, Fakultas MIPA, Universitas Pattimura \\ Jl. Alue Peunyareng, Meulaboh Aceh Barat, 23681, Indonesia \\ Corresponding author e-mail: 1* cukrirahminiani@utu.ac.id
}

\begin{abstract}
Abstrak
Ms.Excel merupakan sebuah aplikasi lembar kerja yang menyediakan menu pengolahan data. Aplikasi pengolahan data pada Ms.Excel dapat diaktifkan secara gratis di menu Toolbar yaitu menu Analysis ToolPak. Berdasarkan menu analisis tersebut hampir seluruh data statitik dapat diselesaikan sama dengan menggunakan aplikasi-aplikasi statistik yang berbayar saat ini. Jika mahasiswa mampu menggunakan Ms.Excel secara optimal pastinya sangat memudahkan dalan hal pengolahan data pada penelitian tugas akhir. Penelitian ini bertujuan untuk mengetahui kemampuan analisis data menggunakan Ms.Excel pada mahasiswa tingkat akhir di Universitas Teuku Umar (UTU). Data kemampuan diperoleh melalui soal pengolahan data yang dikerjakan pada lembar kerja Ms.Excel. Soal meliputi materi statistik deskriptif, penyajian data, uji instrumen dan uji hipotesis. Dari hasil penelitian diperoleh fakta bahwa mahasiswa mampu menghitung statistik deskriptif sebesar 34\%, penyajian data $43 \%, 13 \%$ pada uji instrumen dan terakhir $10 \%$ pada uji hipotesis. Secara kumulatif, kemampuan pengolahan berbasis Ms.Excel pada mahasiswa akhir Universitas Teuku Umar berada pada kategori sedang.
\end{abstract}

Kata Kunci : Ms. Excel, Pengolahan Data.

\begin{abstract}
Ms. Excel is a worksheet application that provides a data processing menu. The data processing application on Ms. Excel can be activated for free on the Toolbar menu, namely the Analysis ToolPak menu. Based on the analysis menu, almost all statistical data can be solved similarly by using current paid statistical applications. If students are able to use Ms. Excel optimally, it certainly makes it very easy in terms of data processing in the final project research. This study aims to determine the ability to analyze data using Ms. Excel in final year students at Teuku Umar University. Capability data is obtained through data processing questions that are done on Ms. Excel worksheets. The questions include descriptive statistical material, data presentation, instrument testing and hypothesis testing. From the results of the study, it was found that students were able to calculate descriptive statistics by 34\%, data presentation 43\%, 13\% on instrument testing and finally $10 \%$ on hypothesis testing. Cumulatively, Ms. Excel-based processing abilities in the final students of Teuku Umar University are in the medium category.
\end{abstract}

Keywords: Ms. Excel, Data Processing.

Article info:

How to cite this article:

C. R. Niani and N. Lewaherilla, "ANALISIS KEMAMPUAN PENGOLAHAN DATA BERBASIS MS. EXCEL PADA MAHASISWA SEMESTER AKHIR UNIVERSITAS TEUKU UMAR”, BAREKENG: J. Il. Mat. \& Ter., vol. 15, no. 02, pp. 203-214, Jun. 2021.

This work is licensed under a Creative Commons Attribution-ShareAlike 4.0 International License.

Copyright $\odot 2021$ Cukri Rahmi Niani, Norisca Lewaherilla 


\section{PENDAHULUAN}

Mahasiswa yang berada pada semester atau yang akan menyelesaikan matakuliah dan sedang menyusun tugas akhir (skripsi) disebut dengan mahasiswa semester akhir [1]. Ketika mahasiswa menyusun tugas akhir, penelitian merupakan pokok permasalahan yang harus dipikirkan dan ditulis dalam bentuk buku. Mahasiswa dituntut untuk memikirkan permasalahan yang terjadi disekitar kampus atau dilingkungan masing-masing. Bentuk penelitian yang diambil dapat bersifat kualitatif atau kuantitatif. Kedua hal tersebut sama-sama melibatkan pengolahan data yang membutuhkan perhitungan dan uji analisis statistik untuk mendapatkan kesimpulan dari permasalahan yang terjadi.

Data merupakan sekumpulan ilustrasi atau keterangan mengenai sesuatu hal bisa berbentuk bilangan atau berbentuk kategori, misalnya: baik, senang, gagal, rusak dan sebagainya [2]. Data juga disebutkan dengan istilah data statistik. Selanjutnya data yang diperoleh disusun dan di sajikan untuk memberi informasi. Bentuk penyajian data dapat berupa kualitatif (gambar, simbul) atau dalam bentuk kuantitatif (tabel) [3]. Data yang telah diperoleh selanjutnya kan dianalisa dan di uji hipotesis secara statistik untuk diambil kesimpulan. Dalam menguji hipotesisi penelitian pengolahan data kuantitatif menjadi salah satu hal yang harus dilakukan [4]. Pengolahan data adalah suatu proses untuk mendapatkan data dari setiap variabel penelitian yang siap dianalisis [5]. Pengolahan data meliputi kegiatan pengeditan data, transformasi data (coding), serta penyajian data sehingga diperoleh data yang lengkap dari masing-masing obyek untuk setiap variabel yang diteliti. Pengolahan data merupakan serangkaian kegiatan yang dilakukan setelah data dikumpulkan. Secara sederhana pengolahan data meliputi penyajian data, perhitungan sari numerik dari data (statistik deskriptif), analisis instrumen dan pengujian hipotesis. Pengolahan data dapat dilakukan secara manual atau menggunakan kalkulator dan menggunakan computer. Dengan komputer terdapat bantuan aplikasi pengolahan data seperti Ms Excel, SPSS, SAS dan lain-lain [6]. Dari aplikasi yang disebutkan hanya Ms. Excel yang dapat di akses secara gratis dan langkah pengerjaan yang sederhana.

Ms.Excel atau Microsoft Office Excel adalah program spreadsheet yang paling mapan, dan termasuk kedalam program teratas di kelasnya. Banyak fasilitas yang ditawarkan oleh Ms. Excel diantaranya kemampuan kalkulasi dengan kompleks formula dan fleksibel, fasilitas pengelolaan database yang sangat mapan dan kemampuan dalam mengolah grafik [7]. Ms Excel merupakan salah satu perangkat untuk pengolahan data secara otomatis melalui program statistik yang ada di dalamnya. Khususnya bagi Ms Excel 2010 yang sudah dilengkapi dengan fitur analisis data statistik. Program aplikasi tersebut dapat diperoleh secara otomatis di akses menu Toolbar. Program statistik dapat digunakan setelah mengaktifkan Analysis ToolPak program menu Add Ins. Selanjutnya menu Data Analysis akan muncul di Toolbar Ms. Excel [8].

Pemilihan perangkat lunak Ms.Excel sebagai alternatif pengolahan data karena aplikasi ini sangat dikenal oleh mahasiswa [9]. Dengan menggunakan Ms.Excel kita dapat mengolah data secara otomatis, dengan formula, menampilkan tabel dan grafik serta manajemen data [10]. Pengolahan data berbasis Ms. Excel juga dapat diperoleh secara gratis dengan bahasa aplikasi yang sederhana dan mudah dipahami. Sama halnya dengan aplikasi statistik lainnya, menggunakan Ms.Excel mahasiswa juga dapat menyelesaikan hampir semua jenis pengolahan data statistik. Beberapa masalah yang dihadapi saat ini adalah kurangnya pengetahuan mahasiswa mengenai pengolahan data berbasis Ms. Excel. Mahasiswa lebih memilih mengolah data secara manual bahkan tanpa menggunaka komputer. Mahasiswa lebih banyak menggunakan perhitungan kalkulator dalam membaca data, misalkan dalam menghitung rata-rata dan menggambar grafik dari data yang diolah. Seiring perkembangan ilmu pengetahuan, tentu langkah-langkah yang demikian sudah tidak efisien bagi mahasiswa, khusus pengolahan untuk data-data dengan variabel yang banyak (big data). Semakin komplek sebuah data maka sangat diperlukan suatu furmulasi yang komplek, semisalkan pengolahan data dari tabel sederhana dan tabel yang tidak sederhana [1].

Tujuan penelitian untuk mengatahui tingkat kemampuan mahasiswa akhir menggunakan MS Excel untuk pengolahan data penelitian. Hasil penelitian ini dapat menjadi informasi awal untuk mengetahui tingkat kemampuan analisa data pada mahasiswa. Selanjutnya informasi yang diperoleh dapat menjadi acuan bagi pengembangan pembelajaran metode analisis data. Selain itu penelitian ini dapat meningkatkan kemampuan analisis data berbasis Ms. Excel pada mahasiswa. 


\section{METODE PENELITIAN}

Metode penelitian ini menggunakan metode penelitian kualitatif dengan pendekatan deskriptif. Penelitian deskriptif merupakan penelitian yang berusaha menggambarkan aturan atau menginterprestasi objek sesuai dengan apa adanya [11], dengan maksud mendeskripsikan fenomena, dimana peneliti ingin mengungkapkan kemampuan pengolahan data pada mahasiswa.

Penelitian mencakup seluruh mahasiswa semester akhir. Mulai dari semester VII sampai semester VIII pada kampus UTU. Sampel penelitian diambil sebanyak 10\% dari keseluruhan pupulasi sesuai dengan yang digagaskan oleh Gay dan Diehl [12]. Sampel diambil secara acak dari setiap fakultas yang ada di ruang lingkup UTU. Teknik yang digunakan dalam penelitian ini adalah teknik tes. Tes merupakan sejumlah soal atau pertanyaan yang digunakan untuk mengukur pengetahuan, bakat dan keterampilan dari subjek penelitian [13]. Untuk mengetahui tingkat kemampuan pengolahan data diperoleh melalui tingkat kebenaran butir-butir soal berbentuk essay yang diberikan. Soal yang diberikan mengenai pengolahan data yang dikerjakan melalui Ms.Excel.

Instrumen penelitian berupa tes dalam bentuk uraian. Cakupan indikator penilaian mencakup indikator pengolahan data statistik [14]. Adapun indikator yang digunakan dalam penelitian ini ditunjukkan pada Tabel 1, sebagai berikut:

\section{Tabel 1. Deskripsi indikator pengolahan data}

\begin{tabular}{ll}
\hline Indikator & Deskripsi \\
\hline Statistik Deskriptif & $\begin{array}{l}\text { Mahasiswa mampu mengeluarkan nilai statistik deskriptif dari data seperti mean, } \\
\text { median, mode, range, skweness, kurtosis dan lain-lain. }\end{array}$ \\
\hline Penyajian Data & $\begin{array}{l}\text { Mahasiswa mampu menampilkan data dalam bentuk tabel frekuensi dan dalam bentuk } \\
\text { histogram }\end{array}$ \\
\hline Analisis Instrumen & Mahasiswa mampu menghitung nilai validitas dan reliabilitas pada instrumen penelitian. \\
\hline Uji Hipotesis & Mahasiswa mampu melakukan uji-t atau uji-z terhadap hipotesis penelitian. \\
\hline
\end{tabular}

Berdasarkan Tabel 1, akan diuraikan item penilaian pada setiap indikator. Uraian indikator yang diukur dapat dilihat pada Tabel 2.

Tabel 2. Pendoman penilaian kemampuan pengolahan data

\begin{tabular}{|c|c|c|}
\hline Indikator & Deskripsi & Skor \\
\hline \multirow{3}{*}{ Statistik Deskriptif } & Jawaban kosong & 0 \\
\hline & $\begin{array}{l}\text { Mampu mengeluar statistik deskriptif seperti mean, mode, standar variansi. } \\
\text { Tetapi tidak menggunakan menu analisis statistik pada Ms. Excel }\end{array}$ & 10 \\
\hline & $\begin{array}{l}\text { Mampu menggunakan menu analisis data pada Ms. Excel untuk mengeluarkan } \\
\text { statistik deskriptif dari data. }\end{array}$ & 10 \\
\hline \multirow{3}{*}{ Penyajian Data } & Jawaban kosong & 0 \\
\hline & $\begin{array}{l}\text { Mampu mengurutkan data dan menyajikan data dalam bentuk tabel frekuensi, } \\
\text { akan tetapi tidak mampu menampilkan histogram }\end{array}$ & 10 \\
\hline & $\begin{array}{l}\text { Mampu menytajikan dalam bentuk tabel frekuensi, menampilkan Histogram data } \\
\text { dan mampu menjelaskan bentuk kenolmalan data. }\end{array}$ & 10 \\
\hline \multirow{4}{*}{ Analisis Instrumen } & Jawaban kosong & 0 \\
\hline & Mampu menentukan koefien korelasi $\left(\mathrm{R}^{2}\right)$ & 10 \\
\hline & Mampu menentukan nilai koefisien Reliabel $\mathrm{R}$ & 10 \\
\hline & $\begin{array}{l}\text { Mampu menyimpulkan nilai validitas dan reliabilitas instrumen terhadap } \\
\text { variabel penelitian. }\end{array}$ & 10 \\
\hline \multirow{4}{*}{ Uji Hipotesis } & Jawaban kosong & 0 \\
\hline & Mahasiswa mampu menentukan pernyataan $\mathrm{H}_{0}$ dan $\mathrm{H}_{\mathrm{a}}$ & 10 \\
\hline & Mampu menentukan nilai sig-dan atau nilai $P$-value menggunakan Ms. Excel & 10 \\
\hline & $\begin{array}{l}\text { Mampu menyimpulkan kesimpulan penelitian dari nilai sig- dan atau nilai } P \text { - } \\
\text { value yang diperoleh. }\end{array}$ & 10 \\
\hline
\end{tabular}

Tingkat kemampuan mahasiswa dianalisis berdasarkan tingkat kebenaran dan kesalahan berdasarkan hasil tes. Untuk mengetahui tingkat kemampuan pemahaman analisis data dideskripsikan hasil tes berdasarkan pedoman kriteria penilaian kecakapan yang disebutkan oleh Sugiono [15] . Kategori seperti yang ditampilkan pada Tabel 3 . 
Tabel 3. Kategori tingkat kemampuan pengolahan data berbasis MS.Excel

\begin{tabular}{ccc}
\hline No & Skor Siswa & Kategori \\
\hline 1 & $0,00-20,00$ & Sangat Rendah \\
\hline 2 & $20,01-40,00$ & Rendah \\
\hline 3 & $40,01-60,00$ & Sedang \\
\hline 4 & $60,01-80,00$ & Tinggi \\
\hline 5 & $80,01-100,00$ & Sangat tinggi \\
\hline
\end{tabular}

\section{HASIL DAN PEMBAHASAN}

\subsection{Hasil}

Penelitian ini dilaksanakan pada mahasiswa semester akhir (semester 7 dan semester 8) di UTU. Untuk mengetahui kemampuan pengolahan data pada mahasiswa diberikan soal tes yang dikerjakan dilembar Ms.Excel. Soal tes terdiri dari 8 (delapan) item yang meliputi materi analisis statistik deskriptif, penyajian data, analisis instrumen dan materi uji hipotesis. Data tes diperoleh melalui tingkat kebenaran jawaban mahasiswa. Tingkat kebenaran dilihat dari segi langkah kerja atau penggunaan perintah-perintah statistik yang ada padalembar kerja Ms.Excel, hasil perhitungan dan kesimpulan. Data tes yang diperoleh dari hasil penelitian pada mahasiswa semester akhir di Universitas Teuku Umar dapat dilihat pada Gambar 1, berikut:

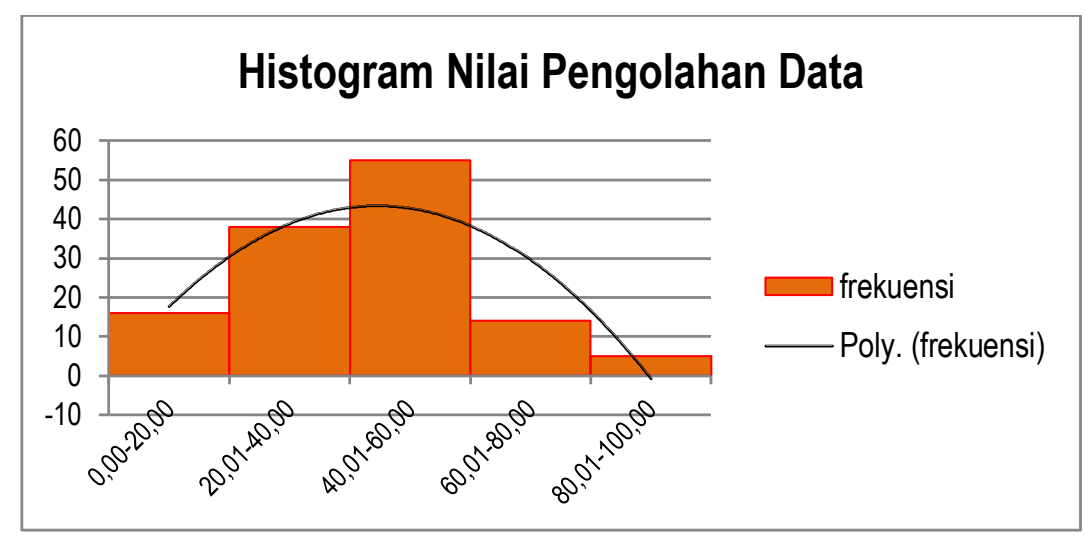

Gambar 1. Data kemampuan pengolahan data berbasis Ms.Excel pada mahasiswa semester akhir Universitas Teuku Umar

Data yang diperoleh berikutnya akan di uji kenormalannya. Uji normalitas dilakukan untuk menilai sebaran data atau variabel apakah berdistribusi normal atau tidak. Jenis uji yang digunakan adalah uji normalitas Kolmogorof Smirnov [16]. Uji normalitas dilakukan dengan menggunakan Ms.Excel. Nilai normalitas data diperoleh seperti terlihat pada Tabel 4, berikut:

Tabel 4. Uji Normalitas Kolmogorov Smirnov

\begin{tabular}{lllll}
\hline $\mathrm{n}$ & $:$ & 250 & $\mathrm{H}_{\mathrm{o}}$ : Sebaran data berdistribusi normal \\
\hline$\propto$ & $:$ & 0,05 & $\mathrm{H}_{1}:$ Sebaran data tidak berdistribusi normal \\
\hline $\mathrm{D}_{\max }$ & $:$ & 0,059 & $\mathrm{D}_{\max }<\mathrm{D}_{\propto, \mathrm{n}}$ & $:$ Terima $\mathrm{H}_{0}$ \\
\hline $\mathrm{D}_{\propto, \mathrm{n}}$ & $:$ & 1,358 & \\
\hline
\end{tabular}

Tabel 4 menjelaskan bahwa data penelitian berdistribusi normal. Dapat dilihat nilai $\mathrm{D}_{\max }<\mathrm{D}_{\propto, \mathrm{n}}$ sehingga disimpulkan data berdistribusi normal. Berikutnya berdasarkan data tes yang diperoleh peneliti akan mengklasifikasikan data tersebut kedalam empat bagian pemecahan masalah. Yaitu data berdasarkan materi statistik deskriptif, penyajian data, analisis instrumen penelitian dan pengujian hipotesis penelitian. Berdasarkan hasil tes secara keseluruhan diperoleh skor kemampuan seperti yang terlihat pada Tabel 5. 
Tabel 5. Kategori Skor Kemampuan Mahasiswa

\begin{tabular}{lcccc}
\hline No & Skor & Frekuensi & $\begin{array}{c}\text { Frekuensi } \\
\text { Komulatif }(\boldsymbol{\%})\end{array}$ & Kategori \\
\hline 1. & $0,00-20,00$ & 16 & $12 \%$ & Sangat rendah \\
\hline 2. & $20,01-40,00$ & 38 & $30 \%$ & Rendah \\
\hline 3. & $40,01-60,00$ & 55 & $43 \%$ & Sedang \\
\hline 4. & $60,01-80,00$ & 14 & $11 \%$ & Tinggi \\
\hline 5. & $80,01-100,00$ & 5 & $4 \%$ & Sangat tinggi \\
\hline
\end{tabular}

Hasil yang disajikan pada Tabel 5, menjelaskan fakta bahwa $12 \%$ mahasiswa masih berada pada kemampuan masih sangat rendah. 30\% mahasiswa berada dalam kategori rendah. Sebanyak $43 \%$ mahasiswa mampu melakukan pengolahan data kategori sedang. Selanjutnya diikuti $11 \%$ dalam kategori tinggi dan hanya $4 \%$ mahasiswa yang termasuk dalam kategori sangat tinggi.

Dari keseluruhan data kemampuan pengolahan data yang diperoleh, lebih lanjut dideskripsikan berdasarkan indikator masing-masing item penilaian. Tingkat kemampuan mahasiswa dibagi kedalam lima kategori, masing-masing kategori mewakili kategori sangat rendah, rendah, sedang, tinggi dan sangat tinggi. Uraian masing-masing kategori sebagai berikut:

\section{a. Kategori mahasiswa dengan kemampuan sangat rendah}

Mahasiswa dengan kemampuan sangat rendah sebanyak 12\% mahasiswa. Sebagian besar mahasiswa tidak memberi jawaban atau kosong dan mahasisiwa hanya menulis ulang soal. Sebagian kecil mahasiswa hanya dapat menampilkan grafik dari data dan tidak dapat menentukan histogram data. Berikut deskripsi mahasiswa dengan kemampuan sangat rendah. Deskripsi untuk setiap indikator dapat dilihat pada Tabel 6.

Tabel 6. Deskripsi Kemampuan Mahasiswa Kategori Berkemampuan Sangat Rendah

\begin{tabular}{|c|c|c|c|}
\hline Indikator & Deskripsi & Skor & $\begin{array}{c}\text { Jumlah } \\
\text { mahasiswa }\end{array}$ \\
\hline \multirow{3}{*}{$\begin{array}{l}\text { Statistik } \\
\text { Deskriptif }\end{array}$} & Jawaban kosong & 0 & 8 \\
\hline & $\begin{array}{l}\text { Mampu mengeluar statistik deskriptif seperti mean, mode, standar } \\
\text { variansi. Tetapi tidak menggunakan menu analisis statistik pada Ms. } \\
\text { Excel }\end{array}$ & 10 & 8 \\
\hline & $\begin{array}{l}\text { Mampu menggunakan menu analisis data pada Ms. Excel untuk } \\
\text { mengeluarkan statistik deskriptif dari data. }\end{array}$ & 10 & 0 \\
\hline \multirow{3}{*}{ Penyajian Data } & Jawaban kosong & 0 & 8 \\
\hline & $\begin{array}{l}\text { Mampu mengurutkan data dan menyajikan data dalam bentuk tabel } \\
\text { frekuensi, akan tetapi tidak mampu menampilkan histogram }\end{array}$ & 10 & 7 \\
\hline & $\begin{array}{l}\text { Mampu menytajikan dalam bentuk tabel frekuensi, menampilkan } \\
\text { Histogram data dan mampu menjelaskan bentuk kenolmalan data. }\end{array}$ & 10 & 1 \\
\hline \multirow{4}{*}{$\begin{array}{l}\text { Analisis } \\
\text { Instrumen }\end{array}$} & Jawaban kosong & 0 & 16 \\
\hline & Mampu menentukan koefien korelasi $\left(\mathrm{R}^{2}\right)$ & 10 & 0 \\
\hline & Mampu menentukan nilai koefisien Reliabel R & 10 & 0 \\
\hline & $\begin{array}{l}\text { Mampu menyimpulkan nilai validitas dan reliabilitas instrumen } \\
\text { terhadap variabel penelitian. }\end{array}$ & 10 & 0 \\
\hline \multirow{4}{*}{ Uji Hipotesis } & Jawaban kosong & 0 & 15 \\
\hline & Mahasiswa mampu menentukan pernyataan $\mathrm{H}_{0}$ dan $\mathrm{H}_{\mathrm{a}}$ & 10 & 1 \\
\hline & $\begin{array}{l}\text { Mampu menentukan nilai sig- dan atau nilai } P \text {-value menggunakan } \\
\text { Ms. Excel }\end{array}$ & 10 & 0 \\
\hline & $\begin{array}{l}\text { Mampu menyimpulkan kesimpulan penelitian dari nilai sig- dan atau } \\
\text { nilai } P \text {-value yang diperoleh. }\end{array}$ & 10 & 0 \\
\hline
\end{tabular}




\section{b. Kategori mahasiswa dengan kemampuan rendah}

Mahasiswa yang memiliki kemampuan rendah sebanyak 38 orang. Sebesar $26 \%$ mahasiswa yang berkemampuan rendah mampu menentukan statistitik deskriptif dengan cara manual. Pada kategori ini masih ada mahasiswa yang tidak memberi jawaban untuk setiap indikator. $46 \%$ mahasiswa dapat menyajikan data dalam bentuk tabel dan histogram. Selanjutnya hanya 3\% mahasiswa yang memberi jawaban untuk indikator ananlisis instrumen dan uji hipitesis. Deskripsi untuk setiap indikator dapat dilihat pada Tabel 7.

Tabel 7. Deskripsi Kemampuan Mahasiswa Kategori Berkemampuan Rendah

\begin{tabular}{|c|c|c|c|}
\hline Indikator & Deskripsi & Skor & $\begin{array}{c}\text { Jumlah } \\
\text { mahasiswa }\end{array}$ \\
\hline \multirow{3}{*}{$\begin{array}{l}\text { Statistik } \\
\text { Deskriptif }\end{array}$} & Jawaban kosong & 0 & 12 \\
\hline & $\begin{array}{l}\text { Mampu mengeluar statistik deskriptif seperti mean, mode, standar } \\
\text { variansi. Tetapi tidak menggunakan menu analisis statistik pada Ms. } \\
\text { Excel }\end{array}$ & 10 & 20 \\
\hline & $\begin{array}{l}\text { Mampu menggunakan menu analisis data pada Ms. Excel untuk } \\
\text { mengeluarkan statistik deskriptif dari data. }\end{array}$ & 10 & 7 \\
\hline \multirow{3}{*}{ Penyajian Data } & Jawaban kosong & 0 & 5 \\
\hline & $\begin{array}{l}\text { Mampu mengurutkan data dan menyajikan data dalam bentuk tabel } \\
\text { frekuensi, akan tetapi tidak mampu menampilkan histogram }\end{array}$ & 10 & 27 \\
\hline & $\begin{array}{l}\text { Mampu menytajikan dalam bentuk tabel frekuensi, menampilkan } \\
\text { Histogram data dan mampu menjelaskan bentuk kenolmalan data. }\end{array}$ & 10 & 6 \\
\hline \multirow{4}{*}{$\begin{array}{l}\text { Analisis } \\
\text { Instrumen }\end{array}$} & Jawaban kosong & 0 & 20 \\
\hline & Mampu menentukan koefien korelasi $\left(\mathrm{R}^{2}\right)$ & 10 & 1 \\
\hline & Mampu menentukan nilai koefisien Reliabel $\mathrm{R}$ & 10 & 0 \\
\hline & $\begin{array}{l}\text { Mampu menyimpulkan nilai validitas dan reliabilitas instrumen } \\
\text { terhadap variabel penelitian. }\end{array}$ & 10 & 0 \\
\hline \multirow{4}{*}{ Uji Hipotesis } & Jawaban kosong & 0 & 30 \\
\hline & Mahasiswa mampu menentukan pernyataan $\mathrm{H}_{0}$ dan $\mathrm{H}_{\mathrm{a}}$ & 10 & 5 \\
\hline & $\begin{array}{l}\text { Mampu menentukan nilai sig- dan atau nilai } P \text {-value menggunakan } \\
\text { Ms. Excel }\end{array}$ & 10 & 2 \\
\hline & $\begin{array}{l}\text { Mampu menyimpulkan kesimpulan penelitian dari nilai sig-dan atau } \\
\text { nilai } P \text {-value yang diperoleh. }\end{array}$ & 10 & 0 \\
\hline
\end{tabular}

\section{c. Kategori mahasiswa dengan kemampuan sedang}

Mahasiswa yang memiliki kemampuan sedang sebanyak 55 orang atau sebesar $43 \%$. Pada kategori ini terlihat 35 mahasiswa mampu menampilkan statistik deskriptif secara manual dan 14 orang mampu menggunakan menu analisis statistik sebagai alat bantunya. Selanjutnya 36 mahasiswa dapat menyajikan data dalam bentuk tabel frekuensi dan bisa menampilkan histogramnya. Dalam kategori sedang terdapat juga mahasiswa yang mampu menentukan nilai korelasi dan reliabel untuk ananlisi instrumen. Terakhir hanya 10 mahasiswa yang dapat menyelesaikan soal pada indikator uji hipotesis yaitu mahahsiswa dapat menentukan $\mathrm{H}_{0}$ dan $\mathrm{H}_{\mathrm{a}}$ pada soal. Deskripsi untuk setiap indikatro dapat dilihat pada Tabel 8 berikut.

Tabel 8. Deskripsi Kemampuan Mahasiswa Kategori Berkemampuan Sedang

\begin{tabular}{|c|c|c|c|}
\hline Indikator & Deskripsi & Skor & $\begin{array}{c}\text { Jumlah } \\
\text { mahasiswa }\end{array}$ \\
\hline \multirow{3}{*}{$\begin{array}{l}\text { Statistik } \\
\text { Deskriptif }\end{array}$} & Jawaban kosong & 0 & 6 \\
\hline & $\begin{array}{l}\text { Mampu mengeluar statistik deskriptif seperti mean, mode, standar } \\
\text { variansi. Tetapi tidak menggunakan menu analisis statistik pada Ms. } \\
\text { Excel }\end{array}$ & 10 & 35 \\
\hline & $\begin{array}{l}\text { Mampu menggunakan menu analisis data pada Ms. Excel untuk } \\
\text { mengeluarkan statistik deskriptif dari data. }\end{array}$ & 10 & 14 \\
\hline \multirow{3}{*}{ Penyajian Data } & Jawaban kosong & 0 & 5 \\
\hline & $\begin{array}{l}\text { Mampu mengurutkan data dan menyajikan data dalam bentuk tabel } \\
\text { frekuensi, akan tetapi tidak mampu menampilkan histogram }\end{array}$ & 10 & 14 \\
\hline & Mampu menyajikan data dalam bentuk tabel frekuensi, menampilkan & 10 & 36 \\
\hline
\end{tabular}




\begin{tabular}{|c|c|c|c|}
\hline & Histogram data dan mampu menjelaskan bentuk kenolmalan data. & & \\
\hline \multirow{4}{*}{$\begin{array}{l}\text { Analisis } \\
\text { Instrumen }\end{array}$} & Jawaban kosong & 0 & 35 \\
\hline & Mampu menentukan koefien korelasi $\left(\mathrm{R}^{2}\right)$ & 10 & 10 \\
\hline & Mampu menentukan nilai koefisien Reliabel R & 10 & 5 \\
\hline & $\begin{array}{l}\text { Mampu menyimpulkan nilai validitas dan reliabilitas instrumen } \\
\text { terhadap variabel penelitian. }\end{array}$ & 10 & 3 \\
\hline \multirow{4}{*}{ Uji Hipotesis } & Jawaban kosong & 0 & 36 \\
\hline & Mahasiswa mampu menentukan pernyataan $\mathrm{H}_{0}$ dan $\mathrm{H}_{\mathrm{a}}$ & 10 & 10 \\
\hline & $\begin{array}{l}\text { Mampu menentukan nilai sig- dan atau nilai } P \text {-value menggunakan Ms. } \\
\text { Excel }\end{array}$ & 10 & 8 \\
\hline & $\begin{array}{l}\text { Mampu menyimpulkan kesimpulan penelitian dari nilai sig- dan atau } \\
\text { nilai } P \text {-value yang diperoleh. }\end{array}$ & 10 & 1 \\
\hline
\end{tabular}

\section{d. Kategori mahasiswa dengan kemampuan tinggi}

Mahasiswa dengan kemampuan tinggi sebanyak 14 atau sebesar 11\%. Sebagian besar mahasiswa mampu menampilkan statistik deskriptif dan menyajikan data dalam bentuk histogram. Pada kategori ini mahasiswa sudah mampu menjawab soal pada indikator analisis instrumen dan uji hipotesis. Deskripsi untuk setiap indikator dapat dilihat pada Tabel 9.

Tabel 9. Deskripsi Kemampuan Mahasiswa Kategori Berkemampuan Tinggi

\begin{tabular}{|c|c|c|c|}
\hline Indikator & Deskripsi & Skor & $\begin{array}{c}\text { Jumlah } \\
\text { mahasiswa }\end{array}$ \\
\hline \multirow{3}{*}{$\begin{array}{l}\text { Statistik } \\
\text { Deskriptif }\end{array}$} & Jawaban kosong & 0 & 0 \\
\hline & $\begin{array}{l}\text { Mampu mengeluar statistik deskriptif seperti mean, mode, standar } \\
\text { variansi. Tetapi tidak menggunakan menu analisis statistik pada Ms. } \\
\text { Excel }\end{array}$ & 10 & 12 \\
\hline & $\begin{array}{l}\text { Mampu menggunakan menu analisis data pada Ms. Excel untuk } \\
\text { mengeluarkan statistik deskriptif dari data. }\end{array}$ & 10 & 2 \\
\hline \multirow{3}{*}{$\begin{array}{l}\text { Penyajian } \\
\text { Data }\end{array}$} & Jawaban kosong & 0 & 0 \\
\hline & $\begin{array}{l}\text { Mampu mengurutkan data dan menyajikan data dalam bentuk tabel } \\
\text { frekuensi, akan tetapi tidak mampu menampilkan histogram }\end{array}$ & 10 & 0 \\
\hline & $\begin{array}{l}\text { Mampu menytajikan dalam bentuk tabel frekuensi, menampilkan } \\
\text { Histogram data dan mampu menjelaskan bentuk kenolmalan data. }\end{array}$ & 10 & 12 \\
\hline \multirow{4}{*}{$\begin{array}{l}\text { Analisis } \\
\text { Instrumen }\end{array}$} & Jawaban kosong & 0 & 1 \\
\hline & Mampu menentukan koefien korelasi $\left(\mathrm{R}^{2}\right)$ & 10 & 5 \\
\hline & Mampu menentukan nilai koefisien Reliabel R & 10 & 8 \\
\hline & $\begin{array}{l}\text { Mampu menyimpulkan nilai validitas dan reliabilitas instrumen } \\
\text { terhadap variabel penelitian. }\end{array}$ & 10 & 3 \\
\hline \multirow{4}{*}{ Uji Hipotesis } & Jawaban kosong & 0 & 1 \\
\hline & Mahasiswa mampu menentukan pernyataan $\mathrm{H}_{0}$ dan $\mathrm{H}_{\mathrm{a}}$ & 10 & 1 \\
\hline & $\begin{array}{l}\text { Mampu menentukan nilai sig- dan atau nilai } P \text {-value menggunakan Ms. } \\
\text { Excel }\end{array}$ & 10 & 4 \\
\hline & $\begin{array}{l}\text { Mampu menyimpulkan kesimpulan penelitian dari nilai sig- dan atau } \\
\text { nilai } P \text {-value yang diperoleh. }\end{array}$ & 10 & 8 \\
\hline
\end{tabular}

\section{e. Kategori mahasiswa dengan kemampuan sangat tinggi}

Mahasiswa dengan kemampuan kategori sangat ini sebanyak 5 orang atau sebesar $5 \%$. Pada kategori ini semua mahasiswa mampu menjawab soal pada indikator statistik deskriptif dan penyajian data. Pada kategori ini 4 orang mahasiswa mampu menyelesaikan semua soal pada setiap indikator. Mahasiswa juga dapat menyimpulkan hasil penelitian dari pengolahan data yang dilakukan. Keseluruhan deskripsi dari tiap indikator terlihat pada Tabel 10. 
Tabel 10. Deskripsi Kemampuan Mahasiswa Kategori Berkemampuan Sangat Tinggi

\begin{tabular}{|c|c|c|c|}
\hline Indikator & Deskripsi & Skor & $\begin{array}{c}\text { Jumlah } \\
\text { mahasiswa }\end{array}$ \\
\hline \multirow{3}{*}{$\begin{array}{l}\text { Statistik } \\
\text { Deskriptif }\end{array}$} & Jawaban kosong & 0 & 0 \\
\hline & $\begin{array}{l}\text { Mampu mengeluar statistik deskriptif seperti mean, mode, standar } \\
\text { variansi. Tetapi tidak menggunakan menu analisis statistik pada Ms. } \\
\text { Excel }\end{array}$ & 10 & 1 \\
\hline & $\begin{array}{l}\text { Mampu menggunakan menu analisis data pada Ms. Excel untuk } \\
\text { mengeluarkan statistik deskriptif dari data. }\end{array}$ & 10 & 5 \\
\hline \multirow{3}{*}{$\begin{array}{l}\text { Penyajian } \\
\text { Data }\end{array}$} & Jawaban kosong & 0 & 0 \\
\hline & $\begin{array}{l}\text { Mampu mengurutkan data dan menyajikan data dalam bentuk tabel } \\
\text { frekuensi, akan tetapi tidak mampu menampilkan histogram }\end{array}$ & 10 & 0 \\
\hline & $\begin{array}{l}\text { Mampu menytajikan dalam bentuk tabel frekuensi, menampilkan } \\
\text { Histogram data dan mampu menjelaskan bentuk kenolmalan data. }\end{array}$ & 10 & 5 \\
\hline \multirow{4}{*}{$\begin{array}{l}\text { Analisis } \\
\text { Instrumen }\end{array}$} & Jawaban kosong & 0 & 0 \\
\hline & Mampu menentukan koefien korelasi $\left(\mathrm{R}^{2}\right)$ & 10 & 1 \\
\hline & Mampu menentukan nilai koefisien Reliabel R & 10 & 4 \\
\hline & $\begin{array}{l}\text { Mampu menyimpulkan nilai validitas dan reliabilitas instrumen } \\
\text { terhadap variabel penelitian. }\end{array}$ & 10 & 3 \\
\hline \multirow{4}{*}{ Uji Hipotesis } & Jawaban kosong & 0 & 0 \\
\hline & Mahasiswa mampu menentukan pernyataan $\mathrm{H}_{0}$ dan $\mathrm{H}_{\mathrm{a}}$ & 10 & 3 \\
\hline & $\begin{array}{l}\text { Mampu menentukan nilai sig- dan atau nilai } P \text {-value menggunakan Ms. } \\
\text { Excel }\end{array}$ & 10 & 4 \\
\hline & $\begin{array}{l}\text { Mampu menyimpulkan kesimpulan penelitian dari nilai sig- dan atau } \\
\text { nilai } P \text {-value yang diperoleh. }\end{array}$ & 10 & 3 \\
\hline
\end{tabular}

Selanjutnya berdasarkan data analisis nilai pada setiap indikator secara umumakan dikategorikan kedalam masing-masing indikator. pendeskripsian bertujuan untuk mengetahui berapa persen mahasiswa yang mampu melakukan pengolahan data berdasarkan item penilaian. Item penilaian meliputi kemampuan analisis statistik deskriptif, penyajian data, analisis instrumen dan uji hipotesis. Berdasar hasil yang diperoleh berikut persentase kebenaran jawaban untuk masing-masing indikator penilaian seperti dilihat pada Gambar 2, berikut.

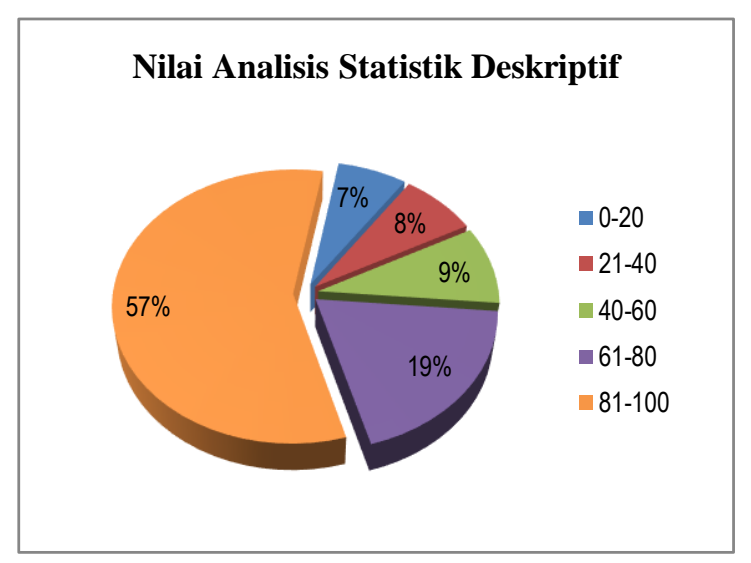

Gambar 2(a). Presentase nilai analisa Statistik Deskriptif

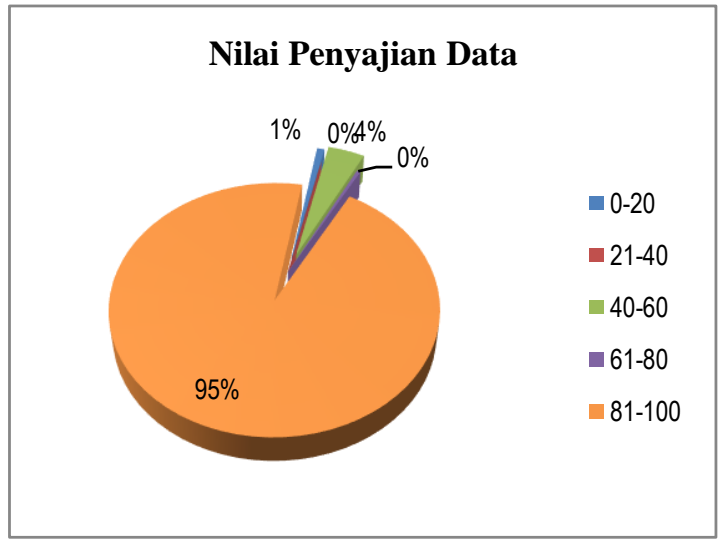

Gambar 2(b). Presentase nilai penyajian Data 


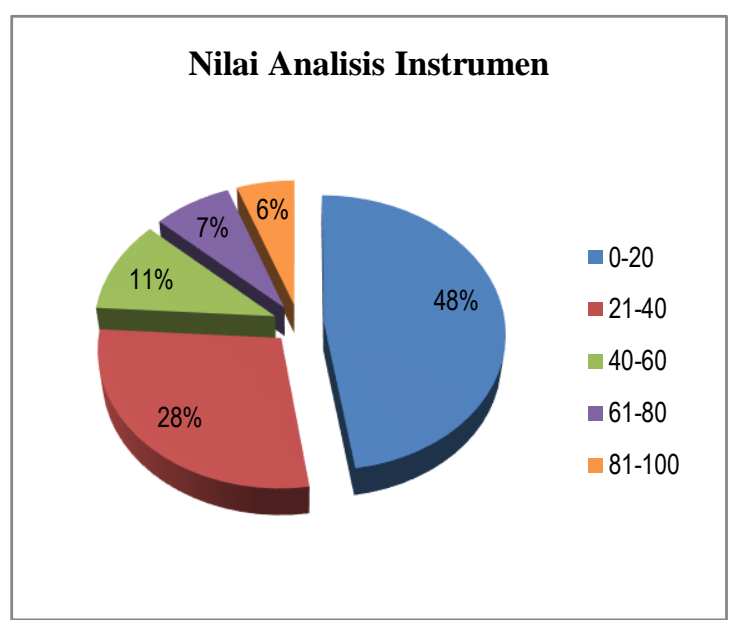

Gambar 2(c). Presentase nilai analisis Instrumen

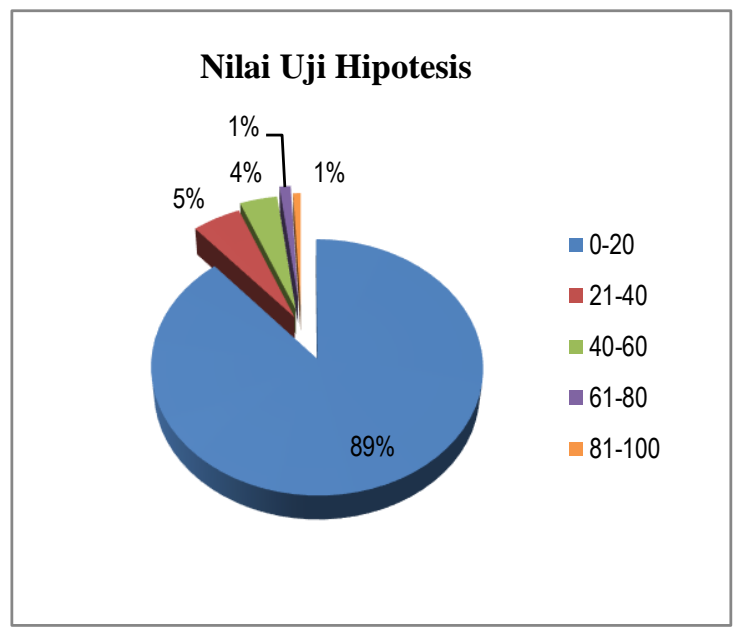

Gambar 2(d). Presentase nilai Uji Hipotesis

Gambar 2 menjelaskan fakta bahwa kemampuan pengolahan data pada mahasiswa hanya sampai pada kemampuan dasar. Artinya mahasiswa hanya mampu menghitung deskriptif data dan penyajian data. Hal tersebut terlihat dari Gambar 2(a) nilai menghitung statistik deskriptif sebanyak 57\% mahasiswa berada pada interval 81-100 atau dalam kategori sangat tinggi, 19\% berada pada rentang 60-80 kategori (tinggi) dan hanya $15 \%$ mahasiswa yang nilai berada dalam kategori rendah atau sangat rendah. Gambar 2(b) memperlihatkan dengan jelas bahwa nilai kemampuan penyajian data mahasiswa dalam kategori sangat tinggi yaitu 95\% mahasiswa nilainya pada rentang 81-100.

Hal sebaliknya pada Gambar 2(c) dan 2(d) nilai mahasiswa sangat rendah pada klasifikasi uji instrumen dan pengujian hipotesis. Pada nilai analisis instrumen terlihat hanya $13 \%$ nilai tinggi dan $11 \%$ dalam kategori sedang dan $76 \%$ lainnya dalam kategori rendah dan sangat rendah. Selanjutnya $89 \%$ mahasiswa berada pada kategori sangat rendah pada kemampuan uji hipotesis. Hal tersebut menjelaskan bahwa $89 \%$ mahasiswa tidak bisa melakukan uji hipotesis pada pengolahan data. Berikutnya presentase kemampuan akan dibandingkan secara kumulatif.

\section{Presentase Kemampuan Pengolahan Data Berbasis Ms.Excel}

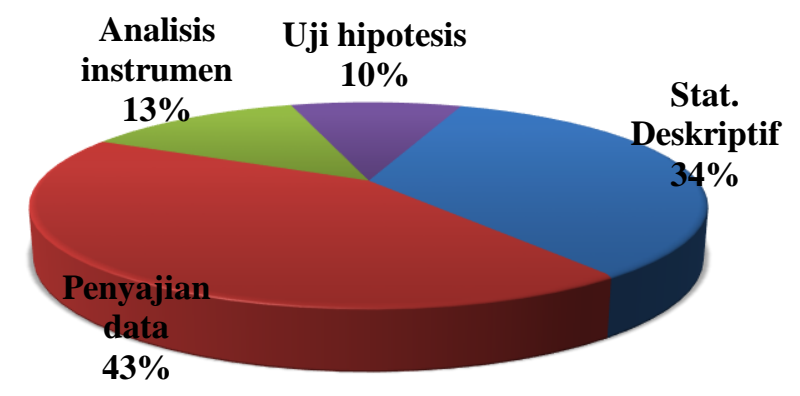

Gambar 3. Pemetaan kemampuan pengolahan data berbasis Ms.Excel pada mahasiswa semester akhir Universitas Teuku Umar.

Gambar 3, menjelaskan bahwa secara keseluruhan kemampuan pengolahan data pada mahasiswa semester akhir UTU, lebih mampu dalam menyajikan data dan perhitungan statistik deskriptif sebesar $43 \%$ dan $34 \%$. Kemudian disusul uji instrumen yakni 13\% dan terakhir pengujian hipotesis sebesar $10 \%$. 


\subsection{Pembahasan}

Merujuk kepada hasil penelitian, kemampuan mahasiswa dalam pengolahan data berbasis Ms. Excel tergolong dalam kategori Sedang. Kemampuan mahasiswa yang berada dalam level sedang sebanyak $43 \%$. Mahasiswa hanya mampu menggunakan Ms. Excel dalam menghitung statistik deskriptif dan menyajikan data dalam bentuk tabel dan histogram. Tingkat kemampuan tersebut menunjukkan mahasiswa hanya mampu melihat bentuk data, akan tetapi tidak mampu menganalisa apakah data tersebut dapat menjawab penelitian ataupun tidak. Mahasiswa tidak mengerti cara uji instrumen dan uji hipotesis. Kemampuan pengolahan data dengan Ms. Excel juga sangat dipengaruhi oleh kemahiran mahasiswa dalam mengoperasikan komputer. Terkadang mahasiswa lebih memilih menggunakan kalkulator untuk pengolahan data daripada komputer. Mahasiswa belum terbiasa dengan aplikasi pengolahan data dengan Ms. Excel. Dari hasil wawancara diketahui bahwa mahasiswa hampir tidak pernah menggunakan lembar kerja Ms.Excel untuk menghitung pengolahan data. Mahasiswa lebih tertarik menggunakan kalkulator yang katanya lebih mudah dipahami.

Selanjutnya, sebagian besar mahasiswa tidak mengerti dengan langkah pengolahan data. Misalkan mahasiswa tidak mengetahui fungsi statistik deskriptif dan tidak tahu mengenai histogram. Selama ini mahasiswa hanya mengetahui rata-rata, dan menanpilkan data dalam bentuk grafik. Hal tersebut selaras dengan kondisi bahwa mahasiswa belum pernah mendapatkan pelatihan dasar mengenai pengolahan data. Khususnya bagi mahasiswa akhir yang sedang melaksanakan penelitian. Kegiatan pelatihan sangat bermanfaat untuk membantu mahasiswa dalam mengolah data penelitian [17].

Selain dari pelatihan pengolahan data, matakuliah statistik juga sangat penting sebagai modal bagi mahasiswa untuk melakukan penelitian. Hal tersebut selaras dengan yang disimpulkan oleh Zulfikri yaitu mata kuliah statistik memiliki pengaruh positif terhadap kemampuan analisa data pada mahasiswa prodi ilmu perpustakaan UIN Ar-Raniry [18]. Pada mata kuliah statistik mahasiswa diperkenalkan dengan statistik deskriptif, bentuk normalitas data, analisis korelasi dan uji hipotesis. Semua materi tersebut merupakan item yang penting dilakukan ketika penelitian dan pengolahan data. Dengan adanya mata kuliah statistik diharapkan dapat membri gambaran bentuk pengolahan data terhadap mahasiswa. Selain itu mahasiswa mengetahui materi pengolahan data secara terpisah artinya tidak kontinu. Misalkan mereka mendapat materi statistik deskriptif dan penyajian data di mata kuliah Statistik I, selanjutnya mereka mendapatkan materi uji instrumen dan uji hipotesis di mata kuliah Statistik II. Kedua mata kuliah tidak kontinu karena sering diajarkan oleh dosen yang berbeda. Sehingga mahasiswa tidak mendapatkan praktik ilmu yang utuh untuk pengolahan data.

Berdasarkan indikator pengolahan data, banyak mahasiswa yang tidak menjawab untuk soal bagian uji intstrumen dan uji hipotesis. Mahasiswa tidak mengetahui uji korelasi dan reliabilitas sebagai salah satu bentuk uji instrumen penelitian. Selanjutnya mahaiswa tidak dapat menentukan pernyataan Hipotesis $\mathrm{H}_{0}$ dan $\mathrm{H}_{\mathrm{a}}$. Kurangnya kemampuan mahasiswa dalam pengolahan data berbasis Ms. Excel dapat juga dikarenakan selama ini, mahasiswa tidak diperkenalkan pengolahan data dengan menggunakan Ms. Excel. Untuk selanjutnya diharapkan mahasiswa ada pembelajaran khusus yang mengajarkan pengolahan data secara lengkap. Artinya mahasiswa tidak hanya bisa menghitung atau menyajikan statistik deskriptif saja. Harapannya mahasiswa bisa menghitung dan mengambil keputusan dari pengolahan data statistik yang dilakukan.

\section{KESIMPULAN}

Berdasarkan penelitian yang telah dilakukan dapat disimpulkan bahwa

1. Kemampuan pengolahan data berbasis Ms.Excel mahasiswa UTU berada pada nilai 40-60 atau masih pada kategori sedang.

2. Nilai tertinggi mahasiswa yaitu pada indikator Penyajian data dan statistik deskriptif .

3. Hanya $4 \%$ dari keseluruhan mahasiswa yang diteliti berada pada kategor Sangat Tinggi yang artinya sudah mampu melakukan pengolahan data dengan Ms. Excel.

\section{UCAPAN TERIMA KASIH}

Penelitian ini merupakan penerima hibah penelitian pada skim Penelitian Dosen Pemula (PDP). Penelitian ini didanai oleh Ristek Brin dengan tahun pendanaan 2020. 


\section{DAFTAR PUSTAKA}

[1] A. Rilman and A. Djamaris, Analisis Data Menggunakan Excel. Jakarta: Universitas Bakrie, 2017.

[2] Sugiyono, Statistik untuk penelitian, 10th ed. Bandung: CV ALFABETA, 2006.

[3] A. Rijali, "Analisis Data Kualitatif [Qualitative Data Analysis]," Alhadharah J. Ilmu Dakwah, vol. 17, no. 33, p. 81, 2019.

[4] H. Patmawati and S. Santika, "Penggunaan Software Microsoft Excel sebagai Alternatif Pengolahan Data Statistika Penelitian Mahasiswa Tingkat Akhir," Seminar Nasional Matematika x. pp. 125-129, 2016.

[5] N. Aedi, Instrumen Penelitian Dan Teknik Pengumpulan Data. Bandung: Universitas Pendidikan Indonesia, 2010.

[6] M. A. Krismanda and S. W. Lukitasari, "Aplikasi Pengolahan Data Statistika Dalam Manajemen Personalia Untuk Pengembangan Guru," Pros. Ilmu Pendidik., vol. 1, no. 2, pp. 136-143, 2015, [Online]. Available: https://jurnal.fkip.uns.ac.id/index.php/pip/article/view/7537\%0Ahttps://jurnal.fkip.uns.ac.id/index.php/pip/article/view/7537 \%0Ahttps://jurnal.fkip.uns.ac.id/index.php/pip/article/view/7537.

[7] I. W. Nuarsa, Jalan Pintas Menguasai Microsoft Excel XP. Yokyakarta: ANDI, 2003.

[8] Sahid, “Analisis Data Statistik dengan MS Excel," Lab. Komput. Jurdik Mat. FMIPA UNY, no. May, pp. 1-14, 2018.

[9] A. Rahman and A. S. Ahmar, "Pengolahan data menggunakan Toolspack Analysis Excel pada guru-guru di Kabupaten Takalar," pp. 193-196.

[10] Asti Riana Putri, "Optimalisasi Penggunaan Microsoft Excel untuk Pengolahan Nilai Raport di SMAN 1 Ngunut Tulungagung," J-Adimas, vol. 3, no. 1, pp. 1-4, 2015.

[11] S. Saidi, "Analisis Kemampuan Mahasiswa Matematika Semester III dalam Menyelesaikan Soal Statistik Dasar,” vol. 2 , no. 2, pp. 38-43, 2013.

[12] A. Asari, B. H. Toloh, and J. R. . Sangari, "Pengembangan ekowisata bahari berbasis masyarakat di desa Bahoi, kecamatan Likupang Barat, kabupaten Minahasa Utara," J. Ilm. Platak, vol. 6, no. 1, pp. 29-41, 2018.

[13] S. Siyoto and A. Sodik, Dasar Metodologi Penelitian, Cetakan 1. Yogyakarta: Literasi Media Publishing, 2015.

[14] I. Maryati, “Analisis kemampuan literasi statistis dalam materi variabilitas,” vol. 3, no. 1, pp. 56-67, 2021.

[15] Romika and Y. Amalia, "Masalah Matematika Menggunakan Media Visual Dan Non Visualpada Materi Bangun Ruang Sisi Datar Di SMP," Mat. J., vol. 1, no. 2, pp. 18-32, 2014.

[16] L. Herawati, Uji Normalitas Data Kesehatan Menggunakan SPSS. 2016.

[17] N. Zakiah, M. Irwanto, and S. N. Fianti, "Pelatihan Pengolahan Data Berbasis Komputer Bagi Peneliti Pemula," J. Pengabdi. UntukMu NegeRI, vol. 4, no. 2, pp. 165-169, 2020, doi: 10.37859/jpumri.v4i2.2073.

[18] Zulfikri, "Pengaruh Mata Kuliah Statistik Terhadap Kemampuan Analisa Data Kuantitatif Mahasiswa Prodi S-1 Ilmu Perpustakaan Angkatan 2011-2012 Fakultas Adab dan Humaniora UIN Ar-Raniry," Libria, vol. 8, no. 1, p. 112, 2016, [Online]. Available: https://jurnal.ar-raniry.ac.id/index.php/libria/article/view/1229. 
